\title{
Tumor-promoting Phorbol Esters Support the In Vitro Proliferation of Murine Pluripotent Hematopoietic Stem Cells
}

\author{
Jerry L. Spivak, Beth B. Hogans, and Robert K. Stuart \\ Division of Hematology, Department of Medicine, The Johns Hopkins University School of Medicine, Baltimore, Maryland 21205; and \\ Division of Hematology/Oncology, Department of Medicine, Medical University of South Carolina, Charleston, South Carolina 29425
}

\section{Abstract}

The effect of tumor-promoting phorbol esters on the in vitro proliferation of mouse pluripotent hematopoietic stem cells (CFU-S) was examined using a short-term in vitro culture system and an 11-d spleen colony assay. Phorbol myristate acetate (PMA, $10^{-7} \mathrm{M}$ ), but not the inert compound phorbol, supported the in vitro survival of day 11 CFU-S for $72 \mathrm{~h}$ in a manner similar to IL 3. PMA also enhanced the effect of IL 3 on the in vitro survival of day 11 CFU-S and as little as $1 \mathrm{~h}$ of exposure to PMA was sufficient for this purpose. The effect of PMA on CFU-S survival in vitro was not mediated by prostaglandins, did not require an established adherent cell population, and was observed at a concentration of $10^{-9} \mathrm{M}$. PMA alone did not enhance the in vitro survival of day 11 CFU-S at very low concentrations of FCS but was still able to potentiate the effect of IL 3 on these cells. PMA also enhanced the in vitro survival of day 11 CFU-S from mice treated with 5-fluorouracil or from marrow cells exposed to merocyanine 540 and light. The interaction of PMA with day 11 CFU-S was not inhibited by a neutralizing antiserum to IL 3 but was inhibited by the protein kinase inhibitor H-7. Together, the data indicate that tumor-promoting phorbol esters interact with pluripotent hematopoietic stem cells. Like IL 3, their effect appears to be permissive and involves stem cells with marrow repopulating ability.

\section{Introduction}

The progenitor cells responsible for maintaining the marrow pools of mature hematopoietic cells are organized in a hierarchy according to their capacity for self-renewal and lineagespecific differentiation (1). The most primitive stem cells maintain the capacity for self-renewal and differentiation to multipotential colony-forming cells. The latter have a restricted capacity for self-replication but are capable of differentiation along multiple pathways. Subsequently, with successive maturation, the commitment to differentiation becomes restricted to one particular pathway.

Address reprint requests to Dr. J. L. Spivak, Division of Hematology, Blalock 1033, The Johns Hopkins Hospital, Baltimore, MD 21205.

Portions of this work were presented at the Annual Meeting of the American Society of Hematology, December 1985, and have been published as an abstract. (1985. Blood. 66[Suppl. 1]:163a. [Abstr.]) 1988.

Received for publication 29 April 1987 and in revised form 13 June

J. Clin. Invest.

(C) The American Society for Clinical Investigation, Inc. 0021-9738/89/01/0100/08 \$2.00

Volume 83, January 1989, 100-107
At each level of commitment, the proliferation and differentiation of hematopoietic progenitor cells are regulated by specific proteins whose target cell specificity may be broad as in the case of IL 3 (2) or granulocyte-macrophage colony-stimulating factor (GM-CSF) ${ }^{1}(3)$, or restricted, as in the case of erythropoietin (4) or colony-stimulating factor 1 (CSF-1) (5). Whereas most of these hematopoietic regulatory proteins have been purified and molecularly cloned, the mechanisms whereby they interact with their target cells are generally unknown. This is mainly because of the difficulties involved in obtaining pure populations of physiologic target cells in adequate quantities for biochemical studies. An alternate approach to this issue is to use biologic response modifiers of known structure and function in conjunction with the regulatory factor of interest and a clonal assay specific for the particular target cell population.

Tumor-promoting phorbol esters are a well-defined group of biologic response modifiers that influence the proliferation and differentiation of a wide variety of cell types, including hematopoietic progenitor cells (6-9). Indeed, the range of known target cell interactions for the phorbol esters amongst hematopoietic progenitor cells is similar to that of IL 3, suggesting that both of these agents may interact with such cells through similar mechanisms. We and others have recently demonstrated that IL 3 promotes the in vitro proliferation of pluripotent hematopoietic stem cells (CFU-S) (2, 10-12). In this report, we describe the effect of tumor-promoting phorbol esters on CFU-S survival in vitro and the interaction of these agents with IL 3 . Our data indicate that tumor-promoting phorbol esters not only enhance the effects of IL 3 on CFU-S proliferation in vitro in a dose-dependent fashion, but also promote the survival of CFU-S in vitro in the absence of the lymphokine.

\section{Methods}

Animals. $\mathrm{B}_{6} \mathrm{D}_{2} \mathrm{~F}_{1}$ mice, 6-10 w old (Jackson Laboratories, Bar Harbor, ME) were housed in sterile cages in groups of five from the time of delivery until killing and received standard mouse chow and acidified water ad lib.

Cell culture studies. Mice were killed by cervical dislocation and marrow cells were flushed from the femurs with $10 \mathrm{mM}$ Hepes-buffered RPMI 1640 medium, (Gibco Laboratories, Grand Island, NY) and $10 \%$ FCS, (Sterile Systems, Logan, UT) into sterile polystyrene tubes and dispersed into single cells by repeated aspiration through a 22-gauge needle. The cell suspension was centrifuged at $400 \mathrm{~g}$ for $5 \mathrm{~min}$ at room temperature and resuspended at a concentration of $1 \times 10^{6}$ cells $/ \mathrm{ml}$ in Hepes-buffered RPMI medium and $10 \%$ FCS. $5 \mathrm{ml}$ of the

1. Abbreviations used in this paper: CFU-S, spleen colony-forming units; 5-FU, 5-fluorouracil; GM-CSF, granulocyte-macrophage colony stimulating factor; MC 540, merocyanine 540; PDBu, phorbol 11,12 dibutyrate. 
cell suspension was placed in either capped polystrene tubes for shortterm incubation or 30-ml flat-bottomed flasks (Corning Glass Works, Corning, $\mathrm{NY}$ ) at $37^{\circ} \mathrm{C}$ in a humidified air $/ 5 \% \mathrm{CO}_{2}$ atmosphere with or without IL 3 or phorbol esters or other agents. At selected times, nonadherent cells were harvested from the culture medium by centrifugation at $400 \mathrm{~g}$ for $5 \mathrm{~min}$ at room temperature while adherent cells were collected by incubating the culture dishes with $0.05 \%$ trypsin and $0.5 \mathrm{mM}$ EDTA for 10-15 min, after which the dishes were scraped with a rubber policeman. The cells were washed once and resuspended in Hepes-buffered RPMI medium and 10\% FCS. Cell number was determined visually in a hemocytometer and viability was evaluated by trypan blue exclusion.

Spleen colony assay. CFU-S were assayed by the method of Till and McCulloch (13) as previously described (10). Briefly, syngeneic recipient mice were exposed to a lethal $(1,050 \mathrm{rad})$ dose of whole body irradiation from a ${ }^{137}$ Cesium source (dose rate $126 \mathrm{rad} / \mathrm{min}$, gamma cell 40, Atomic Energy of Canada, Ottawa, Canada). $4 \mathrm{~h}$ later, 10 irradiated mice were injected with $2 \times 10^{4}$ viable nucleated marrow cells in $0.2 \mathrm{ml}$ Hepes-buffered RPMI medium and 10\% FCS. $11 \mathrm{~d}$ after injection, the mice were killed by cervical dislocation and their spleens were excised, immersed in Carnoy's solution, and after $24 \mathrm{~h}$ transferred to absolute ethanol. $11 \mathrm{~d}$ was chosen because spleen colonies present at day 11 have been found to contain primitive hematopoietic progenitor cells (14). Surface colonies were counted under low magnification (2) without knowledge of the experimental protocol. Endogenous spleen colony formation by irradiated mice not injected with bone marrow cells was negligible, as macroscopic colonies were observed in only $\mathbf{5 0}$ of 181 control spleens in 21 separate experiments.

Reagents. The purified murine IL 3 (15) used in these studies was a gift from Dr. J. N. Ihle (Frederick Cancer Research Facility, Frederick, MD). Phorbol esters (Sigma Chemical Co., St. Louis, MO) were initially dissolved in DMSO at a concentration of $10^{-2} \mathrm{M}$ and stored at $-10^{\circ} \mathrm{C}$ before use; experiments involving these agents were conducted in subdued lighting. Merocyanine 540 was purchased from Eastman Kodak Chemicals (Rochester, NY), 5-fluorouracil from Roche Laboratories (Nutley, NJ) and 1-(5-isoquinolinylsulfonyl)-2-methylpiperazine (H-7) from Calbiochem-Behring Corp. (La Jolla, CA). Purified murine GM-CSF (16) was a gift from Dr. A. W. Burgess (Ludwig Institute for Cancer Research, Melbourne, Australia), pure recombinant G-CSF (17) was obtained from Dr. L. M. Souza (Amgen Biologicals, Thousand Oaks, CA), and rabbit antiserum to murine IL 3 was a gift from Dr. H. Ziltener (Biomedical Research Centre, Vancouver, Canada).

Statistical analysis. The significance of the difference of means was determined using the two-tailed $t$ test. In situations in which more than one test of means was performed, the test for multiple estimates-fixed number was used (18).

\section{Results}

When mouse marrow cells were incubated in vitro in RPMI medium and $10 \%$ FCS, there was a gradual and progressive decline in total cell number that was not influenced by the presence of the inert compound phorbol at a concentration of $10^{-7} \mathrm{M}$ (Fig. 1). When either IL 3 at a concentration of 20 $\mathrm{U} / \mathrm{ml}$ or the tumor promoter phorbol myristate acetate (PMA, $\left.10^{-7} \mathrm{M}\right)$ was added at the start of the incubation, the initial decline in total cell number was more marked over the first 24 $\mathrm{h}$ than in the control cultures $(P<0.001)$, but thereafter the number of cells per flask reached a plateau that remained constant for PMA for up to 144 h of culture; for IL 3, as we have previously reported (10), cell number began to increase after $96 \mathrm{~h}$ of culture.

The survival of CFU-S in vitro, like committed hematopoietic cells, is limited in the absence of specific growth factors. As shown in Table I, however, PMA at a concentration of $10^{-7} \mathrm{M}$

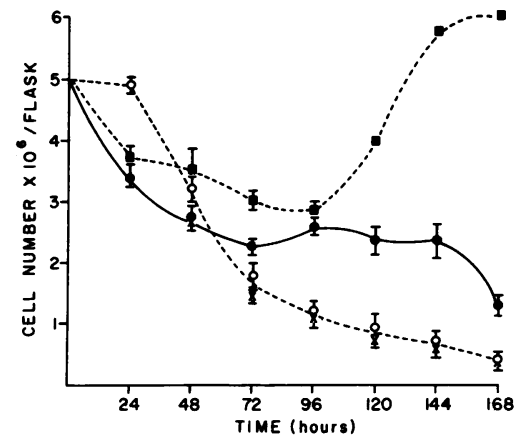

Figure 1. Effect of IL 3, PMA, and phorbol on the in vitro survival of $\mathrm{B}_{6} \mathrm{D}_{2} \mathrm{~F}_{1}$ marrow cells. The marrow cells were cultured in vitro in RPMI medium and $10 \%$ FCS in the presence of $(\square) 20 \mathrm{U} / \mathrm{ml} \mathrm{IL}$ 3 (•) $10^{-7}$ M PMA or (x) $10^{-7} \mathrm{M}$ phorbol or (O) in the absence of these agents. At indi-

cated times, both adherent and nonadherent cells were harvested for counting and viability testing as described in Methods. The data are expressed as the mean \pm SEM.

enhanced the in vitro survival of day $11 \mathrm{CFU}-\mathrm{S}$ over a 72-h period to an extent similar to IL 3, whereas the inert compound phorbol had no effect.

We have previously observed that under the culture conditions used, IL 3 promoted the in vitro proliferation of day 11 CFU-S only in the nonadherent population of the cultured marrow cells (10). When marrow cells cultured in the presence of $10^{-7} \mathrm{M}$ PMA for $72 \mathrm{~h}$ were assayed separately for day 11 CFU-S as adherent and nonadherent cell populations, on average less than one colony per spleen was recovered from the adherent cell population, a frequency not different from that obtained for endogenous spleen colony formation.

Fig. 2 illustrates the effect of $10^{-7} \mathrm{M}$ PMA on the in vitro survival of nonadherent day 11 CFU-S during an exposure period of $144 \mathrm{~h}$ as compared with $20 \mathrm{U} / \mathrm{ml}$ IL 3 or no additives. Although the number of CFU-S declined over the initial $48 \mathrm{~h}$ of culture, the decline was less in the presence of either IL 3 or PMA than when neither was present. By $72 \mathrm{~h}$, in cultures containing IL 3 or PMA, the number of day 11 CFU-S recovered began to increase, but this increase was not sustained for PMA as it was for IL 3. The inert compound phorbol did not promote the survival of day $11 \mathrm{CFU}-\mathrm{S}$ during the same period of exposure, since on average, only $77 \mathrm{CFU}-\mathrm{S}$ per $10^{6}$ marrow cells were recovered in the presence of this agent, a quantity not greater than that obtained in its absence.

Table I. Effect of IL 3, PMA, or Phorbol on the In Vitro Survival of Day $11 \mathrm{CFU}-\mathrm{S}$

\begin{tabular}{lcc}
\hline & \multicolumn{2}{c}{ CFU-S/10 cultured marrow cells* } \\
\cline { 2 - 3 } Additions to cultures & Exp. 1 & Exp. 2 \\
\hline None & $85 \pm 10$ & $55 \pm 20$ \\
IL 3 $(2 \mathrm{U} / \mathrm{ml})$ & $260 \pm 31^{\ddagger}$ & $300 \pm 28^{\ddagger}$ \\
PMA $\left(10^{-7} \mathrm{M}\right)$ & $265 \pm 31^{\ddagger}$ & $205 \pm 29^{\ddagger}$ \\
Phorbol $\left(10^{-7} \mathrm{M}\right)$ & $60 \pm 26$ & $90 \pm 23$ \\
\hline
\end{tabular}

\footnotetext{
* Mean \pm SEM.

₹ Significantly different $(P<0.005)$ from no additions to the culture or $10^{-7} \mathrm{M}$ phorbol. There was no significant difference between $10^{-7}$ $M$ phorbol and no additions to the cultures in either experiment. Marrow cells were cultured in vitro in RPMI medium and 10\% FCS with additions to the cultures as indicated. After $72 \mathrm{~h}$, the cells were harvested for assay of day $11 \mathrm{CFU}-\mathrm{S}$.
} 


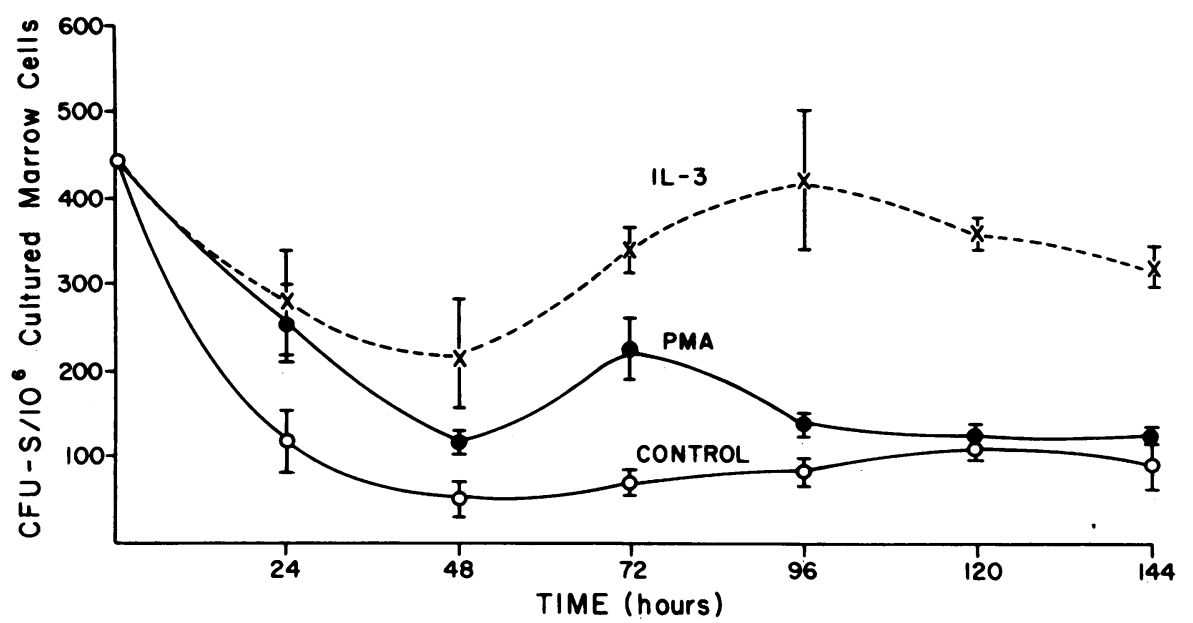

Figure 2. Effect of IL 3 or PMA on the in vitro survival of day 11 CFU-S. Marrow cells were cultured in the presence of 20 $\mathrm{U} / \mathrm{ml}$ IL 3 or $10^{-7} \mathrm{M}$ PMA or no additives (control) for the indicated times and the nonadherent cells harvested for assay of day 11 CFU-S. The data are presented as the mean $\pm S E M$. The difference in the number of CFU-S recovered between PMA and control cultures was significant at 24 $(P<0.01), 48(P<0.005)$, and $72 \mathrm{~h}$ $(P<0.001)$.
To determine if PMA enhanced the proliferation of day 11 CFU-S exposed to IL 3, we incubated mouse marrow cells for 24,48 , or $72 \mathrm{~h}$ with varying concentrations of IL 3 in the presence or absence of $10^{-7}$ M PMA. As shown in Fig. 3, PMA enhanced the effect of IL 3 on the in vitro proliferation of day 11 CFU-S but did not prevent the expected decline in day 11 CFU-S over the first $48 \mathrm{~h}$ of culture (Fig. 2). Furthermore, the enhancement of CFU-S proliferation in vitro by PMA was apparent only at a concentration of 2 or $20 \mathrm{U} / \mathrm{ml}$ of IL 3 over the initial $48 \mathrm{~h}$ of culture and thereafter consistently only at 20 $\mathrm{U} / \mathrm{ml}$ of IL 3.

Although PMA at a concentration of $10^{-7} \mathrm{M}$ or less failed to consistently enhance the in vitro proliferation of day 11 CFU-S exposed to IL 3 at concentrations $<20 \mathrm{U} / \mathrm{ml}$, such enhancement was observed over $72 \mathrm{~h}$ of incubation with $10^{-6}$ M PMA for concentrations of IL $3>0.2 \mathrm{U} / \mathrm{ml}$ (Fig. 4). Indeed, from repeated experiments, the threshold concentration of IL 3 for which a response to PMA was observed was $2.0 \mathrm{U} / \mathrm{ml}$.

As little as $1 \mathrm{~h}$ of exposure to IL 3 was sufficient to promote the in vitro survival of day 11 CFU-S for $96 \mathrm{~h}$ (10) but expo- sure periods of 1-4 $\mathrm{h}$ with PMA alone failed to promote the in vitro survival of these cells (data not shown). However, $1 \mathrm{~h}$ of exposure to PMA was sufficient to enhance the effect of IL 3 (Table II). Because PMA is lipophilic and not likely to be removed from its target cells by washing, we examined the effect of phorbol 12,13 dibutyrate (PDBu), which is less lipophilic than PMA. As shown in Table II, as little as $1 \mathrm{~h}$ of exposure to this phorbol ester also enhanced the effect of IL 3 on the in vitro proliferation of day $11 \mathrm{CFU}-\mathrm{S}$.

To determine the role of FCS in the interaction of phorbol esters and IL 3 on the in vitro survival of day 11 CFU-S, we examined the effect of varying the concentration of FCS. As shown in Table III, at very low concentrations of FCS, PMA alone, in contrast to IL 3, failed to enhance the in vitro survival of day 11 CFU-S. However, PMA was still able to potentiate the effect of IL 3 and potentiation was observed even when the concentration of FCS was increased to $30 \%$.

Tumor-promoting phorbol esters stimulate the production of prostaglandins by macrophages and prostaglandins have been observed to induce quiescent CFU-S into cell cycle (19). To determine if PMA-induced prostaglandin production was

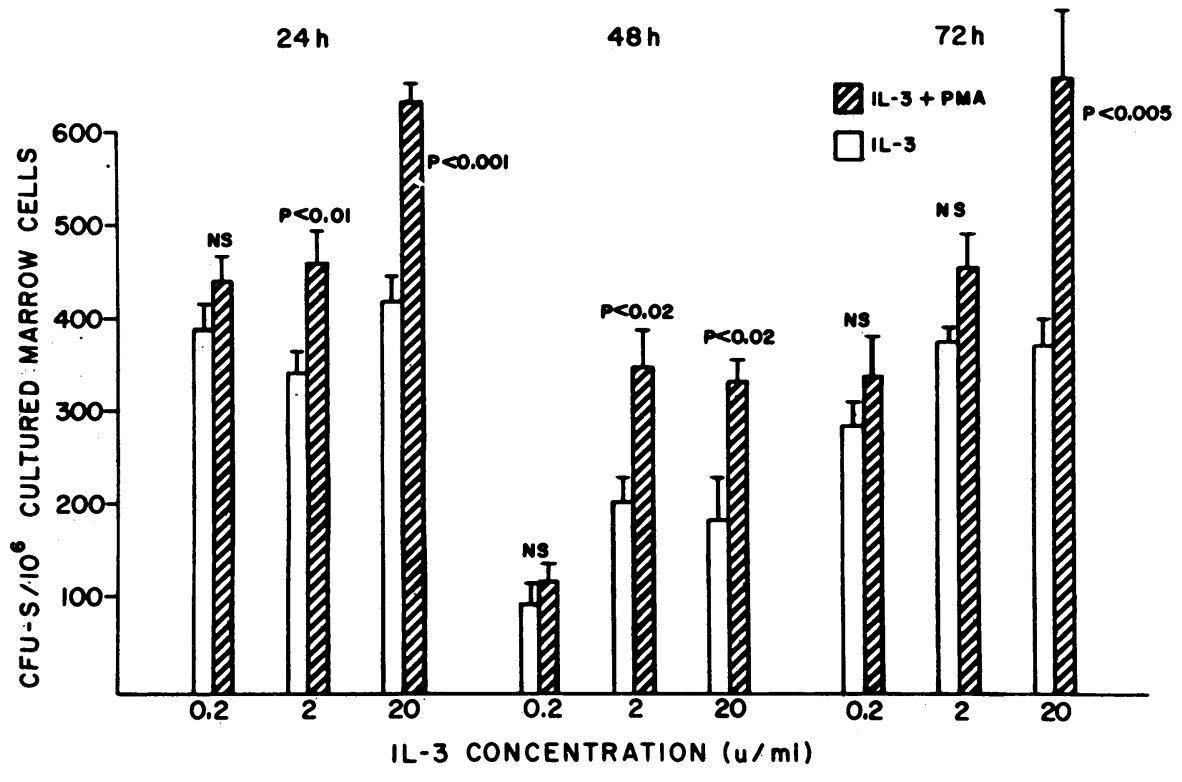

Figure 3. Effect of PMA on the interaction of IL 3 and day 11 CFU.S in vitro. Marrow cells were incubated with IL 3 at the indicated concentrations in the presence or absence of $10^{-7} \mathrm{M}$ PMA for 24, 48, or 72 h. The nonadherent cells were then harvested for assay of day 11 CFU-S. The data are expressed as the mean \pm SEM. 


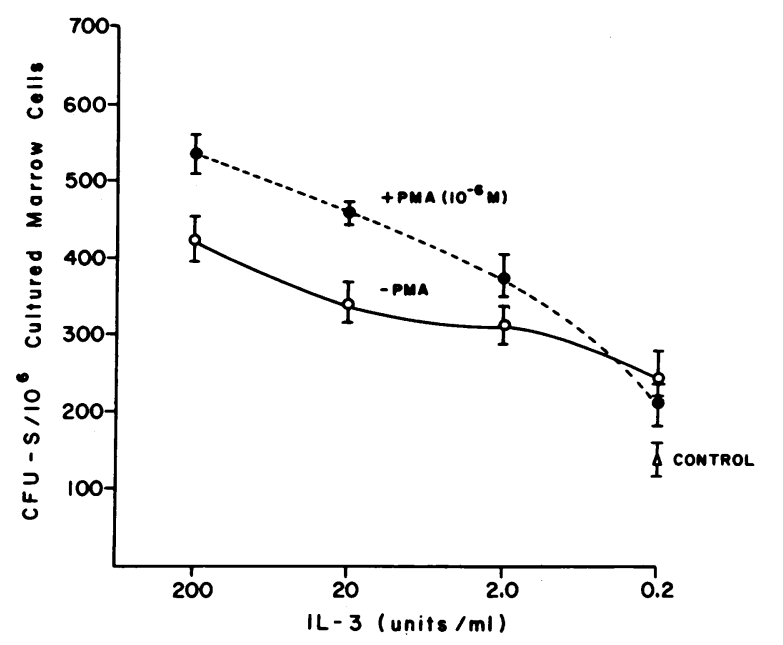

Figure 4. Effect of PMA on the interaction of IL 3 and day 11 CFU-S in vitro. Marrow cells were incubated for $72 \mathrm{~h}$ with various concentrations of IL 3 in the presence or absence of $10^{-6} \mathrm{M}$ PMA. The nonadherent cells were then harvested for assay of day 11 CFU-S. The data represent the mean \pm SEM. Spleen colony formation was significantly greater in the presence of PMA at 2.0 $(P<0.05), 20(P<0.005)$, and $200 \mathrm{U} / \mathrm{ml}(P<0.005)$.

responsible for the enhanced in vitro survival of day 11 CFU-S, we examined the effect of PMA in the presence of indomethacin, an inhibitor of prostaglandin synthesis (20). As shown in Table IV, indomethacin did not diminish the effect of either PMA or IL 3 on day 11 CFU-S proliferation in vitro.

CFU-S are heterogenous with respect to their capacity for self-renewal and marrow repopulation (21). To determine whether tumor-promoting phorbol esters were interacting with CFU-S with self-renewal capacity, we examined the effect of PMA on marrow cells from mice treated with 5-fluorouracil

Table II. Effect of Duration of Exposure In Vitro to PMA or PDBu on the Interaction of IL 3 and Day 11 CFU-S

\begin{tabular}{lcc}
\hline & \multicolumn{2}{c}{$\begin{array}{c}\text { CFU-S/10 cultured } \\
\text { marrow cells* }\end{array}$} \\
\cline { 2 - 3 } \multicolumn{1}{c}{ Additions to cultures } & PMA $\left(10^{-6} \mathrm{M}\right)$ & PDBu $\left(10^{-6} \mathrm{M}\right)$ \\
\hline None & $50 \pm 15$ & $75 \pm 23$ \\
IL 3 $(20 \mathrm{U} / \mathrm{ml})$ & $270 \pm 11^{\ddagger}$ & $280 \pm 21^{\ddagger}$ \\
IL 3 $(20 \mathrm{U} / \mathrm{ml})+$ phorbol esters & & \\
For 1 h & $425 \pm 19^{\ddagger}$ & $360 \pm 7^{\ddagger}$ \\
For $4 \mathrm{~h}$ & $430 \pm 25^{\ddagger}$ & $450 \pm 17^{\ddagger}$ \\
For 24 h & $335 \pm 26^{\ddagger}$ & $400 \pm 17^{\ddagger}$
\end{tabular}

\footnotetext{
* Mean \pm SEM.

${ }^{\ddagger}$ Significantly different from no additions $(P<0.005)$.

Marrow cells were cultured in vitro in RPMI medium and $10 \%$ FCS under the conditions indicated. After 1,4 or $24 \mathrm{~h}$, the cultures containing both IL 3 and phorbol esters were washed and the cells replated with IL $3(20 \mathrm{U} / \mathrm{ml})$ but without PMA or PDBu. At $72 \mathrm{~h}$, the cells were harvested for assay of day 11 CFU-S. When the marrow cells were exposed to IL $3(20 \mathrm{U} / \mathrm{ml})$ and PMA $\left(10^{-6} \mathrm{M}\right)$ continuously for $72 \mathrm{~h}, 440 \pm 12$ spleen colonies $/ 10^{6}$ cultured marrow cells were obtained, whereas for IL $3(20 \mathrm{U} / \mathrm{ml})$ and PDBu $\left(10^{-6} \mathrm{M}\right)$, $380 \pm 32$ spleen colonies $/ 10^{6}$ cultured marrow cells were obtained.
}

Table III. Effect of FCS on the Interaction of PMA and IL 3 With Day 11-CFU-S In Vitro

\begin{tabular}{lc}
\hline \multicolumn{1}{c}{ Additions to cultures } & $\begin{array}{c}\text { CFU-S/10 cultured } \\
\text { marrow cells }\end{array}$ \\
\hline $0.1 \%$ FCS & $155 \pm 22$ \\
$0.1 \%$ FCS + IL $3(20 \mathrm{U} / \mathrm{ml})$ & $690 \pm 28^{\ddagger}$ \\
$0.1 \%$ FCS + PMA $\left(10^{-6} \mathrm{M}\right)$ & $150 \pm 15$ \\
$0.1 \%$ FCS + IL $3(20 \mathrm{U} / \mathrm{ml})+$ PMA $\left(10^{-6} \mathrm{M}\right)$ & $775 \pm 16^{\S}$ \\
$30 \%$ FCS & $130 \pm 17$ \\
$30 \%$ FCS + IL $3(20 \mathrm{U} / \mathrm{ml})$ & $365 \pm 15^{\prime \prime}$ \\
$30 \%$ FCS + PMA $\left(10^{-6} \mathrm{M}\right)$ & $245 \pm 28^{\prime \prime}$ \\
$30 \%$ FCS + IL 3 $(20 \mathrm{U} / \mathrm{ml})+$ PMA $\left(10^{-6} \mathrm{M}\right)$ & $445 \pm 15^{9}$ \\
\hline
\end{tabular}

* Mean \pm SEM.

‡ Significantly different from $0.1 \%$ FCS $(P<0.001)$.

${ }^{8}$ Significantly different from $0.1 \%$ FCS $+20 \mathrm{U} / \mathrm{ml} \mathrm{IL} 3(P<0.025)$.

"Significantly different from $30 \%$ FCS $(P<0.001)$.

' Significantly different from $30 \%$ FCS + IL $3(20 \mathrm{U} / \mathrm{ml})(P<0.025)$. Marrow cells were cultured in RPMI medium and the indicated concentration of FCS with or without IL 3 or PMA. After $72 \mathrm{~h}$, the marrow cells were harvested for assay of day $11 \mathrm{CFU}-\mathrm{S}$. The results represent data from two separate experiments.

(5-FU) (21) or on marrow treated with merocyanine 540 (MC 540) and exposure to light (22). As shown in Table V, PMA not only supported the in vitro survival of day $11 \mathrm{CFU}-\mathrm{S}$ from the marrow of mice treated with 5-FU, it also enhanced the effect of IL 3 on these cells. Interestingly, the effect of either PMA $\left(10^{-6} \mathrm{M}\right)$ or IL $3(20 \mathrm{U} / \mathrm{ml})$ appeared to be equivalent when examined separately, in contrast to the situation with untreated marrow cells (Fig. 2). More importantly, when marrow purged by exposure to MC 540 and light was used as the source of target cells, twice the number of day 11 CFU-S was recovered after a 72-h period of incubation in presence of PMA $\left(10^{-6} \mathrm{M}\right)$ than with IL $3(20 \mathrm{U} / \mathrm{ml})$ (Table V).

The difference in sensitivity between untreated marrow and MC 540-treated marrow to the trophic effects of PMA was particularly evident when the dose of PMA was varied. As shown in Fig. 5, the PMA dose-response curve for CFU-S

Table IV. Effect of Indomethacin on the Interaction between PMA, IL 3, and Day 11 CFU-S In Vitro

\begin{tabular}{lc}
\hline \multicolumn{1}{c}{ Additions to cultures } & $\begin{array}{c}\text { CFU-S/10 cultured } \\
\text { marrow cells* }\end{array}$ \\
\hline None & $80 \pm 12$ \\
Indomethacin $\left(2 \times 10^{-7} \mathrm{M}\right)$ & $105 \pm 16$ \\
IL 3 $(2 \mathrm{U} / \mathrm{ml})$ & $375 \pm 51^{\ddagger}$ \\
IL 3 $(2 \mathrm{U} / \mathrm{ml})+$ indomethacin $\left(2 \times 10^{-7} \mathrm{M}\right)$ & $420 \pm 16^{\ddagger}$ \\
PMA $\left(10^{-6} \mathrm{M}\right)$ & $185 \pm 20^{\ddagger}$ \\
PMA $\left(10^{-6} \mathrm{M}\right)+$ indomethacin $\left(2 \times 10^{-7} \mathrm{M}\right)$ & $220 \pm 37^{\S}$ \\
\hline
\end{tabular}

* Mean \pm SEM.

${ }^{\ddagger}$ Significantly different from no additions or $2 \times 10^{-7} \mathrm{M}$ indometha$\operatorname{cin}(P<0.001)$.

Significantly different from no additions or $2 \times 10^{-7} \mathrm{M}$ indometha$\operatorname{cin}(P<0.025)$.

Marrow cells were cultured in RPMI medium and 10\% FCS under the conditions indicated. After $72 \mathrm{~h}$ the cells were harvested for assay of day 11 CFU-S. 
Table V. Effect of PMA and IL 3 On the In Vitro Survival of Day 11 CFU-S from 5-FU or MC 540-treated Marrow

\begin{tabular}{llc}
\hline & \multicolumn{2}{c}{ CFU-S/10 cultured marrow cells* } \\
\cline { 2 - 3 } \multicolumn{1}{c}{ Additions to cultures } & $\begin{array}{c}\text { After 5-FU } \\
\text { treatment }\end{array}$ & $\begin{array}{c}\text { MC 540-treated } \\
\text { cells }\end{array}$ \\
\hline None & $150 \pm 55$ & $175 \pm 90$ \\
IL 3 $(20 \mathrm{U} / \mathrm{ml})$ & $255 \pm 95^{\ddagger}$ & $300 \pm 75^{\ddagger}$ \\
PMA $\left(10^{-6} \mathrm{M}\right)$ & $275 \pm 90^{\ddagger}$ & $790 \pm 55^{\ddagger}$ \\
IL 3 $(20 \mathrm{U} / \mathrm{ml})+$ PMA $\left(10^{-6} \mathrm{M}\right)$ & $400 \pm 85^{8}$ & $925 \pm 25^{\S}$ \\
\hline
\end{tabular}

* Mean \pm SEM.

¥ Significantly different from no additions $(P<0.02)$.

8 Significantly different from PMA $\left(10^{-6} \mathrm{M}\right)(P<0.05)$.

Marrow cells were obtained from mice that had received $150 \mathrm{mg} / \mathrm{kg}$ 5-FU intravenously $3 \mathrm{~d}$ previously or from normal mice and incubated in vitro for $45 \mathrm{~min}$ with $15 \mu \mathrm{g} / \mathrm{ml} \mathrm{MC}-540$ in the presence of light. The cells were then cultured in vitro in RPMI medium and $10 \%$ FCS with additions to the cultures as described above for $72 \mathrm{~h}$ before harvesting for assay of day 11 CFU-S. Control cultures from untreated marrow cells yielded 55-69 spleen colonies in the absence of IL 3 and 360-455 colonies in the presence of $20 \mathrm{U} / \mathrm{ml} \mathrm{IL} 3$.

survival in vitro using untreated marrow cells was flat over a 1,000-fold difference in PMA concentration. By contrast, when MC 540-treated marrow cells were used, a concentration-dependent increase in sensitivity to PMA was observed.

To determine whether phorbol esters promoted the in vitro survival of day 11 CFU-S by inducing the production of IL 3

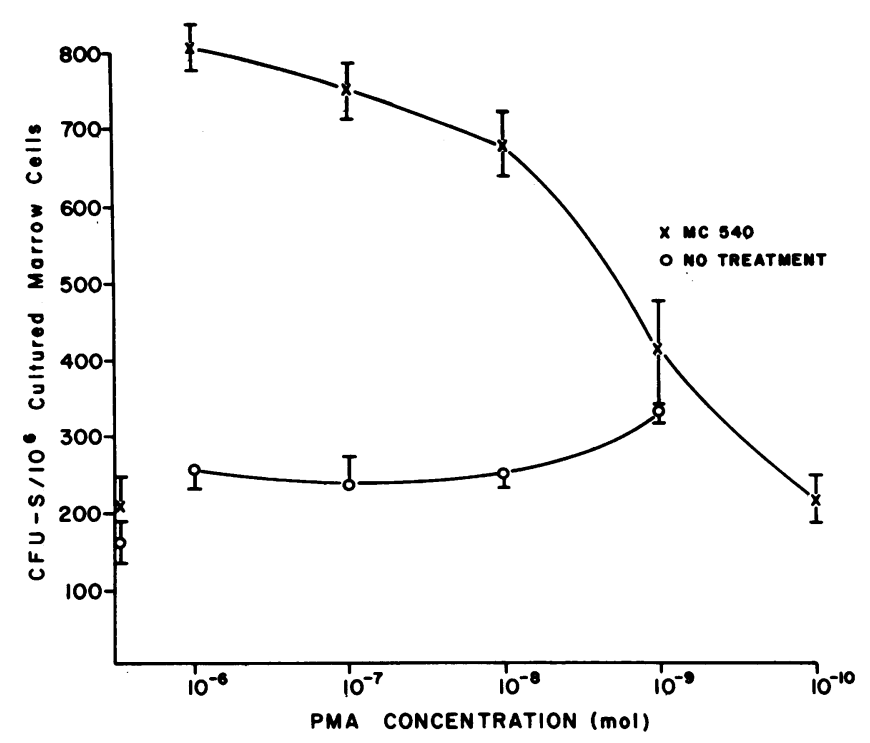

Figure 5. Effect of PMA concentration on the in vitro survival of day 11 CFU-S from untreated marrow or marrow treated with MC 540. Marrow cells were either cultured in RPMI medium and 15\% FCS with the indicated concentrations of PMA or exposed to $15 \mu \mathrm{g} / \mathrm{ml}$ MC 540 and light for 45 min before incubation with PMA. After 72 $h$, the nonadherent cells were harvested for spleen colony assay. The data are expressed as the mean \pm SEM. (0) Significantly different from controls of $10^{-6} \mathrm{M}(P<0.025), 10^{-7} \mathrm{M}(P<0.05), 10^{-8} \mathrm{M}(P$ $<0.01)$, and $10^{-9} \mathrm{M}(P<0.001)$. (X) Significantly different from controls at $10^{-6} \mathrm{M}(P<0.001), 10^{-7} \mathrm{M}(P<0.001), 10^{-8} \mathrm{M}$ $(P<0.001), 10^{-9} \mathrm{M}(P<0.02)$, and $10^{-10} \mathrm{M}(P<0.05)$.
Table VI. Effect of IL 3 Antiserum on the Interaction of PMA and IL 3 on Day 11 CFU-S In Vitro

\begin{tabular}{lc}
\hline \multicolumn{1}{c}{ Additions to cultures } & $\begin{array}{c}\text { CFU-S/10 cultured } \\
\text { marrow cells* }\end{array}$ \\
\hline Normal serum $(1: 100)$ & $205 \pm 13$ \\
PMA $\left(10^{-7} M\right)+$ normal serum $(1: 100)$ & $595 \pm 27$ \\
PMA $\left(10^{-7} \mathrm{M}\right)+$ IL 3 antiserum $(1: 100)$ & $585 \pm 53$ \\
IL $3(2 \mathrm{U} / \mathrm{ml})+$ normal serum $(1: 100)$ & $600 \pm 30$ \\
IL 3 $(2 \mathrm{U} / \mathrm{ml})+$ IL 3 antiserum $(1: 100)$ & $250 \pm 24^{\ddagger}$ \\
\hline
\end{tabular}

* Mean \pm SEM.

¥ Significantly different from $2 \mathrm{U} / \mathrm{ml}$ IL 3 plus normal serum ( $P$ $<0.001$ ).

Marrow cells were incubated in vitro for $45 \mathrm{~min}$ with $15 \mu \mathrm{g} / \mathrm{ml}$ MC-540 in the presence of light and then cultured in RPMI medium and $10 \%$ FCS with the additions described above for $72 \mathrm{~h}$ before harvesting for assay of day 11 CFU-S. A 1:200 dilution of the IL 3 antiserum inhibited the proliferation of the IL 3-dependent cell line DA-1 by $86 \%$ in the presence of $2 \mathrm{U} / \mathrm{ml}$ of IL 3 .

from marrow accessory cells, we examined the effect of a neutralizing rabbit antiserum to IL 3 on the in vitro interaction of PMA and day 11 CFU-S. As shown in Table VI, neither normal rabbit serum nor a 1:100 dilution of the neutralizing rabbit IL 3 antiserum inhibited the proliferation of day $11 \mathrm{CFU}-\mathrm{S}$ in the presence of PMA. By contrast, this same dilution of IL 3 antiserum inhibited the proliferation of day $11 \mathrm{CFU}-\mathrm{S}$ in the presence of IL 3 by $60 \%$.

To determine if the interaction of phorbol esters with day 11 CFU-S was mediated by protein kinase activation, we examined the effect of the protein kinase inhibitor $\mathrm{H}-7$ on this interaction. As shown in Table VII, H-7, at a concentration of $10 \mu \mathrm{M}$, completely inhibited the stimulation of day $11 \mathrm{CFU}-\mathrm{S}$ proliferation by PMA. This concentration of $\mathrm{H}-7$ also inhibited the effect of a $20 \mathrm{U} / \mathrm{ml}$ concentration of IL 3 by $60 \%$. That the number of day $11 \mathrm{CFU}-\mathrm{S}$ was not reduced to less than the baseline level indicates that the suppressive effect of $\mathrm{H}-7$ was not a consequence of nonspecific toxicity.

Because PMA could not promote the in vitro survival of day 11 CFU-S at very low concentrations of FCS, it was possible that the phorbol ester might be potentiating the effect of other growth factors present in FCS. To study this issue with

Table VII. Effect of the Protein Kinase Inhibitor $\mathrm{H}-7$ on the Interaction of PMA and IL 3 with Day 11 CFU-S In Vitro

\begin{tabular}{lc}
\multicolumn{1}{c}{ Additions to cultures } & $\begin{array}{c}\text { CFU-S/10 cultured } \\
\text { marrow cells }\end{array}$ \\
\hline None & $100 \pm 45$ \\
PMA $\left(10^{-7} M\right)$ & $400 \pm 25$ \\
PMA $\left(10^{-7} M\right)+\mathrm{H}-7(10 \mu M)$ & $70 \pm 25^{\ddagger}$ \\
IL $3(20 \mathrm{U} / \mathrm{ml})$ & $550 \pm 35$ \\
IL $3(20 \mathrm{U} / \mathrm{ml})+\mathrm{H}-7(10 \mu M)$ & $240 \pm 43^{\ddagger}$
\end{tabular}

\section{* Mean \pm SEM.}

‡ Significantly different from no exposure to H-7 $(P<0.001)$. Marrow cells were incubated in vitro for $45 \mathrm{~min}$ with $15 \mu \mathrm{g} / \mathrm{ml}$ MC-540 in the presence of light and then cultured in RPMI medium and $10 \%$ FCS with the additions described above for $72 \mathrm{~h}$ before harvesting for assay of day 11 CFU-S. 
Table VIII. Effect of GM-CSF, G-CSF, and Erythropoietin on the In Vitro Survival of Day 11 CFU-S

\begin{tabular}{lc}
\hline \multicolumn{1}{c}{ Additions to cultures } & $\begin{array}{c}\text { CFU-S/10 cultured } \\
\text { marrow cells* }\end{array}$ \\
\hline None & $105 \pm 25$ \\
GM-CSF $(100 \mathrm{U} / \mathrm{ml})$ & $90 \pm 31^{\ddagger}$ \\
Erythropoietin $(2 \mathrm{U} / \mathrm{ml})$ & $165 \pm 22^{\ddagger}$ \\
G-CSF $(500 \mathrm{U} / \mathrm{ml})$ & $300 \pm 41^{\S}$ \\
IL 3 $(20 \mathrm{U} / \mathrm{ml})$ & $305 \pm 30^{\S}$ \\
PMA $\left(10^{-7} \mathrm{M}\right)$ & $345 \pm 27^{\S}$ \\
G-CSF $(500 \mathrm{U} / \mathrm{ml})+$ PMA $\left(10^{-7} \mathrm{M}\right)$ & $440 \pm 22^{\prime \prime}$ \\
G-CSF $(500 \mathrm{U} / \mathrm{ml})+\operatorname{IL~} 3(20 \mathrm{U} / \mathrm{ml})$ & $510 \pm 35^{\| \prime}$ \\
\hline
\end{tabular}

* Mean \pm SEM.

‡ Not significantly different from no additions.

${ }^{5}$ Significantly different from no additions $(P<0.001)$.

"Significantly different from either $20 \mathrm{U} / \mathrm{ml}$ IL 3 or $10^{-7}$ M PMA alone $(P<0.01)$.

Marrow cells were cultured in vitro in RPMI and $10 \%$ FCS with additions to the cultures as described above. After $72 \mathrm{~h}$, the cells were harvested for assay of day $11 \mathrm{CFU}-\mathrm{S}$.

respect to hematopoietic growth factors, we examined the effect of exogenous pure mouse GM-CSF, pure recombinant G-CSF, and pure recombinant erythropoietin on the in vitro survival of day $11 \mathrm{CFU}-\mathrm{S}$. The concentrations of these factors used was based on the optimal concentration for the in vitro proliferation of their respective target cells. As shown in Table VIII, G-CSF enhanced the in vitro survival of day $11 \mathrm{CFU}-\mathrm{S}$, whereas GM-CSF and erythropoietin did not. G-CSF also stimulated the proliferation of MC 540-treated marrow cells in the same fashion as IL $3\left(290 \pm 20\right.$ CFU-S/ $10^{6}$ cultured marrow cells as compared with $195 \pm 25$ CFU-S in its absence, $P$ $<0.02$ ). Furthermore, not only was the effect of G-CSF on day 11 CFU-S survival similar to that of IL 3, but the combined effects of G-CSF and PMA, and G-CSF and IL 3 on the day 11 CFU-S were equivalent (Table VIII), suggesting that the same target cell population was involved.

\section{Discussion}

The mechanisms governing the proliferation of CFU-S are not well understood, but recently it was demonstrated that IL 3 supports the proliferation of these cells in vitro (10). In this study, we examined interaction of tumor-promoting phorbol esters on the in vitro survival of CFU-S and the effect of these agents on the interaction between IL 3 and CFU-S in vitro. This approach was chosen for three reasons. First, tumor-promoting phorbol esters have the same target cell specificity as IL 3 with respect to hematopoietic progenitor cells in in vitro clonal assays (6-9), but their effect on CFU-S has not been examined. Second, tumor-promoting phorbol esters are chemically well-defined molecules that activate protein kinase $\mathrm{C}$ (23) and it has recently been demonstrated that IL 3 also activates protein kinase $C$ in its target cells (24). Third, both we and others have recently demonstrated that tumor-promoting phorbol esters support the in vitro proliferation of IL 3-dependent cell lines in serum-free medium in the absence of the lymphokine $(25,26)$, suggesting that the phorbol esters and IL 3 share a common mechanism of action, at least with respect to certain cell types.
To study the effect of the phorbol esters on day 11 CFU-S, we used a short-term in vitro culture system without an established adherent layer in which the survival of pluripotent hematopoietic stem cells is restricted in the absence of IL 3 (10). Even in the presence of the lymphokine in this system, there is an initial decline in CFU-S number, suggesting, as has been observed by Suda et al., using an in vitro clonal assay, that the role of the IL 3 in enhancing the proliferation of CFU-S is a permissive one (27).

Although the inert parent alcohol phorbol, and therefore its vehicle, had no effect on the in vitro survival of day 11 CFU-S, active tumor promotors such as PMA or PDBu enhanced the in vitro survival of these cells. The effect of PMA was remarkably like that of IL 3, although restricted in its extent. Neither agent, although present continuously at high concentrations, completely prevented the initial decline both in cell number and CFU-S recovery during the first $48 \mathrm{~h}$ of incubation, which characterizes the behavior of marrow cells cultured in vitro in RPMI medium and $10 \%$ FCS. Thereafter, both cell number and CFU-S recovery increased, although the increments were lower and not sustained for the phorbol esters. Indeed, with freshly explanted marrow, a concentration-dependent effect of PMA on day 11 CFU-S survival was not apparent.

Like IL 3, PMA enhanced the in vitro survival of day 11 CFU-S in marrow obtained from mice treated with 5-FU or from marrow cells exposed to MC 540 and light, treatments that are known to selectively spare CFU-S with self-renewal and marrow repopulating ability $(21,22)$. Whereas the response of 5-FU-treated marrow cells to PMA was not significantly different from that observed with untreated cells, the response of MC 540-treated marrow cells was dramatic. Indeed, PMA was more active than IL 3 and a clear concentration-dependent effect was observed. This suggests that the blunted response observed with untreated marrow may reflect either dilution of the target cell pool or a summation of the effects of PMA on different marrow cell populations.

The interaction of PMA with day 11 CFU-S was not mediated by prostaglandins, as indomethacin did not inhibit it, nor was stimulation of endogenous IL 3 production involved, as demonstrated by the experiment using a neutralizing antiserum to IL 3. Furthermore, the phorbol esters appeared not to be acting through stimulation of adherent cells, since day 11 CFU-S were not recovered from this population in excess of that expected from endogenous spleen colony formation alone and replating did not diminish the effect of PMA or PDBu. Recently, Kerk et al., using different culture conditions, described an adherent murine marrow cell population with in vivo repopulating ability (28). Whether the CFU-S population we describe and that described by Kerk et al. are similar remains to be determined.

Exposure of marrow cells simultaneously to both PMA and IL 3 resulted in an increment in the number of day 11 CFU-S recovered but the effect was essentially additive, never synergistic, and not observed at low concentrations of IL 3. However, as little as $1 \mathrm{~h}$ of exposure to PDBu was sufficient to enhance the effect of IL 3 and the replating involved did not diminish the effect of the phorbol esters. It seems unlikely, therefore, that the phorbol esters were acting through an accessory cell population.

Although a high concentration of FCS was not required for potentiation of the effect of IL 3 by PMA, the phorbol esters 
alone had no effect on day 11 CFU-S in a low concentration of FCS. This suggests that their interaction with CFU-S required the presence of other factors. PMA binds to proteins in FCS and such binding might facilitate interactions with its target cells. Alternatively, protein binding might serve to reduce nonspecific toxicity due to this agent.

Because phorbol esters are known to enhance the effect of growth factors such as GM-CSF $(8,29)$, and FCS, which contains these factors, was required for PMA activity, we examined the effect of purified GM-CSF, G-CSF, and erythropoietin on the in vitro survival of day 11 CFU-S. Of these, a significant response was obtained only with G-CSF. This is the first identification of a hematopoietic growth factor other than IL 3 that enhances the in vitro survival of CFU-S. Our data also indicate that the effects of G-CSF, PMA, and IL 3 on day 11 CFU-S survival were equivalent. Because the combination of G-CSF and PMA yielded more colonies than either did separately, it is unlikely that PMA alone acted merely to potentiate the effect of trace amounts of G-CSF or other growth factors present in the FCS.

That G-CSF promoted the in vitro survival of day 11 CFU-S was unexpected, since this growth factor was previously reported to be restricted in its ability to sustain the proliferation of multipotent hematopoietic progenitor cells in vitro (30). However, the ability of a hematopoietic growth factor not solely derived from lymphocytes to regulate the proliferation of CFU-S adds a new dimension to their physiology and could explain the observation that endotoxin enhances endogenous spleen colony formation (31).

Protein kinase activation appeared to be involved in the interaction of both phorbol esters and IL 3 with day 11 CFU-S since the isoquinoline sulfonylpiperazine, $\mathrm{H}-7$, a potent protein kinase $C$ inhibitor $\left(K_{\mathrm{i}}=6 \mu \mathrm{M}\right)(32)$, suppressed the stimulation of day $11 \mathrm{CFU}-\mathrm{S}$ proliferation by both. As $\mathrm{H}-7$ also inhibits cycle nucleotide-dependent protein kinases (32), the exact kinases involved in this instance cannot be stated with certainty. Nevertheless, since both phorbol esters and IL 3 are known to activate protein kinase $C$ in their target cells, it seems likely that activation of this kinase was involved in the interaction of these agents with day 11 CFU-S.

Together, the data presented indicate that tumor-promoting phorbol esters enhance the in vitro survival of CFU-S. Like IL 3, their effect appears to be a permissive one, involves stem cells with marrow repopulating ability, does not require accessory cells and protein kinase activation appears to be involved. Tumor-promoting phorbol esters should prove useful in investigating the proliferative behavior of CFU-S.

\section{Acknowledgments}

The excellent technical assistance of Mrs. Evelyn Connor and Mrs. Mary Ann Isaacs is gratefully acknowledged.

This work was supported by grant AM-16702 from the National Institute of Diabetes and Digestive and Kidney Diseases.

\section{References}

1. Ogawa, M., P. N. Porter, and T. Nakahata. 1983. Renewal and commitment to differentiation of hemopoietic stem cells (an interpretive review). Blood. 61:823-829.

2. Goldwasser, E., J. N. Ihle, M. B. Prystowski, J. Rick, and G. Van Zant. 1983. The effect of interleukin-3 on hemopoietic precursor cells.
In Normal and Neoplastic Hematopoiesis. Alan R. Liss, Inc., New York. 301-309.

3. Burgess, A. W., J. Camakaris, and D. Metcalf. 1977. Purification and properties of colony stimulating factor from mouse lung conditioned medium. J. Biol. Chem. 252:1998-2003.

4. Krantz, S. B., and E. Goldwasser. 1984. Specific binding of erythropoietin to spleen cells infected with the anemia strain of Friend virus. Proc. Natl. Acad. Sci. USA. 81:7574-7578.

5. Stanley, E. R., and P. M. Heard. 1977. Factors regulating macrophage production and growth. Purification and some properties of the colony-stimulating factor from medium conditioned by mouse $\mathrm{L}$ cells. J. Biol. Chem. 252:4305-4312.

6. Stuart, R. K., and J. A. Hamilton. 1980. Tumor-promoting phorbol esters stimulate hematopoietic colony formation in vitro. Science (Wash. DC). 208:402-404.

7. Sieber, F., R. K. Stuart, and J. L. Spivak. 1981. Tumor-promoting phorbol esters stimulate myelopoiesis and suppress erythropoiesis in cultures of mouse bone marrow cells. 1981. Proc. Natl. Acad. Sci. USA. 78:4402-4406.

8. Burgess, A. W., and N. A. Nicola. 1983. Effects of 12-0-tetradecanoylphorbol-13-acetate (TPA) on the proliferation of granulocyte-macrophage colony-forming cells. Blood. 61:575-579.

9. Long, M. W., L. L. Gragowski, C. H. Heffner, and L. A. Boxer. 1985. Phorbol diesters stimulate the development of an early murine progenitor cell. J. Clin. Invest. 76:431-438.

10. Spivak, J. L., R. R. L. Smith, and J. N. Ihle. 1985. Interleukin 3 promotes the in vitro proliferation of murine pluripotent hematopoietic stem cells. J. Clin. Invest. 76:1613-1621.

11. Garland, J. M., and S. Crompton. 1983. A preliminary report: preparations containing interleukin-3 (IL-3) promote proliferation of multipotential stem cells (CFU-S) in the mouse. Exp. Hematol. 11:757-761.

12. Rennick, D. M., F. D. Lee, T. Yokota, K-I. Arai, H. Cantor, and G. J. Nabel. 1985. A cloned mast cell growth factor $\mathrm{cDNA}$ encodes a multilineage hematopoietic growth factor. Multiple activities of interleukin 3. J. Immunol. 134:910-914.

13. Till, J. E.; and E. A. McCulloch. 1961. A direct measurement of the radiation sensitivity of normal mouse bone marrow cells. Radiat. Res. 14:213-222.

14. Magli, M. C., N. N. Iscove, and N. Odartchenko. 1982. Transient nature of early haematopoietic spleen colonies. Nature (Lond.). 295:527-529.

15. Ihle, J. N., J. Keller, L. Henderson, F. Klein, and E. Palaszynski. 1982. Procedures for the purification of interleukin 3 to homogeneity. J. Immunol. 129:2431-2436.

16. Metcalf, D., G. R. Johnson, and A. W. Burgess. 1980. Direct stimulation by purified GM-CSF of the proliferation of multipotential and erythroid G-CSF precursor cells. Blood. 55:138-147.

17. Souza, L., T. Boone, J. Gabrilove, P. H. Lai, M. Zsebo, D. M. Murdock, V. R. Chazin, J. Bruszewski, H. Lu, K. K. Chen, J. Barendt, E. Platzer, M. A. S. Moore, R. Mertlesmann, and K. Welte. 1986. Recombinant human granulocyte colony-stimulating factor: effects on normal and leukemic myeloid cells. Science (Wash. DC). 232:61-65.

18. Dixon, N. J., and F. J. Massey. 1983. Introduction to statistical analysis. McGraw-Hill Book Co., New York. 174-181.

19. Feher, I., and J. Gidali. 1974. Prostaglandin $E_{2}$ as stimulator of haemopoietic stem cell proliferation. Nature (Lond.). 247:550-551.

20. Flower, F., R. Gryglewski, K. Herbaczynska-Cedro, and J. R. Vane. 1972. Effects of antiinflammatory drugs on prostaglandin biosynthesis. Nature (Lond.). 238:104-106.

21. Bradley, T. R., and G. S. Hodgson. 1979. Properties of haematopoietic stem cells surviving 5-fluorouracil treatment: evidence for a pre-CFU-S cell? Nature (Lond.). 281:381-382.

22. Meagher, R. C., F. Sieber, and J. L. Spivak. 1983. Susceptibility to merocyanine 540-mediated photosensitization: a differentiation marker on murine hematopoietic progenitor cells. J. Cell. Physiol. 116:118-124.

23. Nishizuka, Y. 1984. The role of protein kinase $C$ in cell surface 
synal transduction and tumor promotion. Nature (Lond.). 308:693698.

24. Farrar, W. L., T. P. Thomas, and W. B. Anderson. 1985. Altered cytosol/membrane enzyme redistribution on interleukin-3 activation of protein kinase C. Nature (Lond.). 315:235-237.

25. Hogans, B. B., and J. L. Spivak. 1986. Tumor-promoting phorbol esters stimulate the proliferation of interleukin-3 dependent cells. Exp. Hematol. 14:54a.

26. Whetton, A. D., C. M. Heyworth, and T. M. Dexter. 1986. Phorbol esters activate protein kinase $\mathrm{C}$ and glucose transport and can replace the requirement for growth factor in interleukin-3-dependent multipotent stem cells. J. Cell Sci. 84:93-104.

27. Suda, T., J. Suda, M. Ogawa, and J. N. Ihle. 1985. Permissive role of interleukin 3 (IL-3) in proliferation and differentiation of multipotential hemopoietic progenitors in culture. J. Cell Physiol. 124:182-190.

28. Kerk, D. K., E. A. Henry, A. C. Eaves, and C. J. Eaves. 1985.
Two classes of primitive pluripotent hemopoietic progenitor cells: separation by adherence. J. Cell. Physiol. 125:127-134.

29. Stuart, R. K., J. A. Hamilton, L. L. Sensenbrenner, and M. A. S. Moore. 1981. Regulation of myelopoiesis in vitro: partial replacement of colony-stimulating factors by tumor-promoting phorbol esters. Blood. 57:1032-1042.

30. Metcalf, D., and N. A. Nicola. 1983. Proliferative effects of purified granulocyte colony-stimulating factor (G-CSF) on normal mouse hemopoietic cells. J. Cell. Physiol. 116:198-206.

31. Boggs, D. R., J. C. Marsh, P. A. Chervenick, G. E. Cartwright, and M. M. Wintrobe. 1968. Factors influencing hematopoietic spleen colony formation in irradiated mice VI: the different effects of foreign plasma, endotoxin, and bleeding on colony-forming cell kinetics. $R a$ diat. Res. 35:68-77.

32. Hidaka, H., M. Inagaki, S. Kawamoto, and Y. Sasaki. 1984. Isoquinolinesulfonamides, novel and potent inhibitors of cyclic nucleotide-dependent protein kinase and protein kinase C. Biochemistry. 23:5036-5041. 